\title{
State responsibility as a panacea to international terrorism
}

\author{
Tobiloba O. Awotoye \\ Department of Public Law, Lead City University, Ibadan, Oyo State, Nigeria
}

Email address:

tobilobaawotoye@yahoo.com

To cite this article:

Tobiloba O. Awotoye. State Responsibility as a Panacea to International Terrorism. Humanities and Social Sciences. Vol. 1, No. 1, 2013, pp. 28-45. doi: 10.11648/j.hss.20130101.15

\begin{abstract}
The ultimate dream and goal of every State under the membership of the United Nations is to live every single day in peace without any fear of terror. As reflected in the aims and objectives of the United Nations in its Charter, this is one of the major reasons why the Organization was in fact established. Unfortunately, we now live in a world where no State can afford to sleep even with one eye closed. This is the tragedy of a world lived in fear of terror. Although terrorism is not a new development, modern international terrorism is and most states, especially the Western States, live in constant fear of any imminent Terrorist attack. Be it freedom fighters or terrorists, the truth is no good words can be used to describe any act of terror because of its effects on innocent civilians and the whole community/state at large. This paper explains terrorism in the context of countering it by evaluating the efforts of the United Nations and how these efforts have helped in suppressing and eradicating its evils. It also seeks to evaluate the collective effort of states in fighting this evil menace.
\end{abstract}

Keywords: International Terrorism, State Responsibility, Human Rights

\section{International Terrorism in Context}

According to Shaw ${ }^{1}$, the foundations of international law as it is understood today lie firmly in the development of Western culture and political organization. The development of the relationship between States dates back to thousands of years (for instance, a treaty was signed over 4,500 years ago between the rulers of Lagash and Utah ${ }^{2}$. However, international law between states, as they are now, has developed to cover various grounds in order to ensure not only peaceful relationship between states but also to strengthen peace and order in the world ${ }^{3}$. Every individual have basic set of principles, doctrines and ideals which guide their various activities. This is also the case in every organization, state, or entity having the legal personality to act as one. Within a State there exist various rules, laws, statutes, treaties, and most importantly the constitution

\footnotetext{
${ }^{1}$ M. Shaw, International Law, $6^{\text {th }}$ Edition, Cambridge

${ }^{2}$ A. Nussbaum, A Concise History of the Law of Nations, (Macmillan, 1954) 12

${ }^{3}$ R. Bernhardt, Encyclopedia of Public International Law, (Vol VII, NorthHolland, 1984) 150 where Preiser noted that modern international law began in the $17^{\text {th }}$ century with the problems of Spain and the Halsburg countries; See also G. Scott, The Rise and Fall of the League of Nations, (London 1973) 19-42.
}

(which is the grundnorm ${ }^{4}$ ) which decides the legality of every action. International $\mathrm{Law}$ is an embodiment of international legal system which governs the relationships of states, organisations and peoples ${ }^{5}$.

This legal system is influenced by political, economic, social and cultural processes because it involves states with diversities $^{6}$. As Lenin ${ }^{7}$ also emphasised, for states to coexist peacefully and international cooperation to be achieved, international Law is important- this is in fact the basis of international law. International Law is not a 'command' as reflected by the Austinian school of Jurisprudence $^{8}$, it is a set of agreed rules which must be respected and obeyed in the interest of international peace

\footnotetext{
${ }^{4}$ N. Babbic and D. Zolo, 'Hans Kelsen, The Theory of Law and the International Legal System: A Talk', (1998) 9 EJIL 355-667

${ }^{5} \mathrm{R}$ Jennings and A Watts, Oppenheim 's International Law, (Vol I, OUP, $9^{\text {th }}$ Ed, 1992) 4

${ }^{6} \mathrm{M}$ Dixon and R McCorquodale, Cases and Materials on International Law, ( $4^{\text {th }}$ Ed, OUP, 2003) 1

${ }^{7}$ V Lenin, The National Liberation Movement in the East, (Foreign Language Publishing House, Moscow, 1957) 240

${ }^{8} \mathrm{~J}$ Austin and J Brown (eds), The Austinian Theory of Law: Being an Edition of Lectures I, V, and VI of Austin's "Jurisprudence" and of Austin's "Essay on the Uses of the Study of Jurisprudence" with Critical Notes and Excurses, (London: J Murray, 1906) 331
} 
and unity 9 .

At the end of the First World War which lasted for around four years the Peace Treaty was signed in 1919 by states which led to the formation of the League of Nations. Even though it possessed a lot of weaknesses (ranging from its inability to successfully confront determined aggressors such as Japan in 1931; and also being mostly comprised of European Nations) ${ }^{10}$, the League of Nations lasted for about twenty seven years. It was later succeeded by the United Nations Organisation in 1946 as a result of the Second World War which greatly threatened world peace and order. To this effect, States felt the need for an international legal instrument to ensure that another outbreak of war or its equivalent no longer arises in the world. This led to the enactment of the UN Charter ${ }^{11}$. The Charter is an international legal instrument which influences international decisions between nations, international persons and also every other international legal instruments. It is the grundnorm of international law. It enforces both the promotion and enforcement of international peace and security ${ }^{12}$.

However, one of the challenges to world peace in the modern world is terrorism which if allowed lingering for a long time without being adequately checked could lead to genocide, crime against humanity and even an outbreak of war defeating the whole purpose of the Charter. According to Maogoto ${ }^{13}$, the events that led to the First and Second World Wars were acts of State terrorism that was left unchecked by international law ${ }^{14}$. What makes Terrorism a menace is not only in the fear and panic it creates but also in its casualties. It is a threat to any international legal order $^{15}$.

Although it is clear to all what danger terrorism poses to any civilized society, the appalling events of September 11, 2001 shook the entire world. It was considered as an attack on all countries of the world as the victims were not only Americans ${ }^{16}$. Although stricter measures were introduced and enforced by the United Nations subsequent to the September 11 attacks, terrorist attacks have not ceased and terrorists seem to be more motivated in the furtherance of their lethal course. On the 11th of March, 2004 the Spanish capital was attacked just 3 days before the general elections. This attack, popularly referred to as M-11 led to the death of 191 civilians and wounded 1800 others. On the 7th of

\footnotetext{
${ }^{9} \mathrm{Y}$ Korovin et al, International Law (Academy of Sciences of the USSR Institute of Law, Foreign Languages Publishing House, Moscow) 15-18

${ }^{10}$ S Lyman (ed), The China White Paper, (Stanford, 1967) 10; G Scott, The Rise and Fall of the League of Nation

${ }^{11}$ See the Preamble to the UN Charter.

${ }^{12}$ Article 39 of the UN Charter

${ }^{13} \mathrm{~J}$ Maogoto, Battling Terrorism: Legal Perspectives on the Use of Force and the War on Terror, (Ashgate Publishing Ltd, 2005)

${ }^{14}$ Pp 22-27

${ }^{15}$ A Roberts, 'Terrorism and International Order' in L Freedman et al (eds), Terrorism and International Order, (Routledge \& Keegan Paul, 1986) 7

${ }^{16}$ Brazilian Minister of Foreign Affairs, Celso Lafer, in his speech at the XXII Meeting of Consultation of the ministers of Foreign Affairs in the Organization of American States of Washington DC (September 21, 2001), available at http://www.patriotresource.com/wtc/intl/0921/brazil.html accessed 4 July 2012
}

July, 2005, it was the turn of the United Kingdom to feel the wrath of these perpetrators of evil as the London Underground Tube was attacked. The Intelligence and Security Committee Report recorded the number of casualties as a total of 52 deaths and 700 people were injured $^{17}$.

Authors 18 have been forced to ask questions as to whether the Charter recognises terrorism as an international crime. This shows there still exists a lot of uncertainties as to as to whether terrorism is really an international crime. With the uncertainties surrounding modern international terrorism Western states now treat it as an 'armed attack' or 'international armed conflict'. After the September 11 attack on USA, for instance, the United States and United Kingdom attacked Afghanistan in retaliation or 'selfdefence' after issuing a warning to the Taliban de facto government that it should 'turn over the leaders of $\mathrm{Al}$ Qaeda to the United States, close all terrorist training camps in Afghanistan, and provide the United States with full access to the camps to confirm their closure ${ }^{19}$ which the de facto government refused to comply with ${ }^{20}$. This escalated into an international armed conflict.

No matter how beautiful a text on international terrorism appears to be, it would have been a failure if no attempt is made at defining terrorism. Terrorism is an interesting as well as evil subject. This is a song the international community has been singing for decades, especially since the attacks on the twin towers of the World Trade centre, The Pentagon and also the attempted attack on the United States Capitol Building all within a day. Attempting a definition of international terrorism is always a strong foundation to any text on terrorism.

Diverse definitions have been advanced by states, jurists and philosophers on what terrorism means. The tragedy, however, is that the more one reads these definitions the more the confusion on what it truly entails. There is no consensus about how it should be defined. Even though we know it when we see it just like pornographyl the search for a real all-encompassing definition of terrorism has

\footnotetext{
${ }^{17}$ Intelligence and Security Committee Report into the London Terrorist Attacks on 7 July 2005, Presented to the Parliament by the Prime Minister by command of Her Majesty, May 2006, available at http://www.officialdocuments.gov.uk/document/cm67/6785/6785.pdf accessed 4 July 2012

${ }^{18}$ A Cassesse, International Criminal Law, (2 ${ }^{\text {nd }}$ ed, OUP, 2008) 162-165; A Cassesse, 'Terrorism as an International Crime', in A Bianchi (ed), Enforcing International Law Norms Against Terrorism (Hart Publishing, 2004); P Robinson, 'The Missing Crimes' in A Cassesse et al (eds), The Rome Statute of the International Criminal Court: A Commentary, (Vol I, OUP, 2002) 497-525; V Proulx, "Rethinking the Jurisdiction of the International Criminal Court in the Post-September $11^{\text {th }}$ Era: Should Acts of Terrorism Qualify as Crimes against Humanity?" (2004) American University International Law Review, Vol 19, No 5, pp 1009-1089; A Schmid, "The Response Problem as a Definition Problem" in J Lutz and B Lutz (eds), Global Terrorism (Vol I, SAGE, 2008) 7; R Cryer, "Terrorism and the International Criminal Court" (2003) 82 REFORM: Journal of the Australian Law Reform Commission, pp 14-16

${ }^{19}$ S Murphy, "Terrorism and the Concept of 'Armed Attack' in Article 51 of the UN Charter”, (2002) 43 Harvard Int'l Law Journal, p 41

${ }^{20} \mathrm{R}$ Chandrasekaran, "Taliban Refuses to Surrender bin Laden: US Develops Options for Military Action”, 19 Sept 2001 Washington Post at A1
} 
become a search for the Holy Grail ${ }^{21}$. We know it when we see it. We feel it when it happens. It does not take a special tribunal of enquiry to determine that the events of $9 / 11$ were acts of terror as recognised under any domestic law and indeed under international law. ${ }^{22}$

Although international terrorism recently became an household name and a normal expression used by the media, especially in the western nations, terrorism is in actual fact not a recent phenomenon as history makes it one of the oldest world wars that has never been won. It is easy to tell when a crime has been committed domestically because of its manifestations. In most common and civil laws, anyone who kills another human being without any reason to defend such an act is guilty of murder. Such a person becomes a criminal or a murderer upon conviction. This is so for other crimes that offends societal moral and legal values. It is always a difficult task for any judge to determine if an accused person standing trial is a terrorist than it is for the judge to determine if that person is an ordinary criminal guilty of murder. ${ }^{23}$

When viewed from the angle of its manifestations, terrorism becomes just like every other crime. In Nigeria, for example, different cases of kidnapping have been recorded. Kidnapping of foreign nationals and wealthy Nigerians is now prevalent especially in the northern part of Nigeria and also in Delta State ${ }^{24}$. This happens not only in Nigeria, but also in all nations of the world. So the question now is how is a terrorist different from the ordinary criminal OR what is the difference between terrorism and the ordinary crime?

Defining terrorism is never an easy task. Even though defining terrorism in clear terms is very unlikely it is not hard to describe especially for those who have experienced it. As was earlier mentioned, international terrorism is not a twenty first century development. As Saul noted, terrorism did not enter into political discourse until the 18th century even though it began as early as the 14 th century ${ }^{25}$. In the early times, terrorism was an instrument of the state. Terrorism was a tool used by the Western states to gain respect and loyalty both home and abroad. A new breed of terrorism has since developed beginning with the commencement of the cold War as states fought other states for ideological, political and religious reasons through small non-governmental organisations. Terrorists and terrorist groups continued to advance in tactics as religious

\footnotetext{
${ }^{21}$ G. Levitt, Is "Terrorism” Worth Defining?, 13 Ohio N.U.L., 1986, 97

${ }^{22}$ J. Addicott, Legal and Policy Implications for a New Era: The "War on Terror", THE SCHOLAR: ST. MARY'S LAW REVIEW ON MINORITY ISSUES (2002) 209.

${ }^{23}$ Amerasinghe, C.F. The Essence of the Structure of International Responsibility, in Maurizio Ragazzi (ed.), INTERNATIONAL RESPONSIBILITY TODAY: ESSAYS IN MEMORY OF OSCAR SCHACHTER 3-6 (2005).

24 See http://www.fco.gov.uk/en/travel-and-living-abroad/travel-advice-bycountry/sub-saharan-africa/nigeria/ (last accessed on 13 September 2012)

${ }^{25}$ B Saul, Attempts to Define 'Terrorism' in International Law, Netherlands I.L.R. 2005 57-61; See also M. Vohryzek-Bolden and Ors, Domestic Terrorism and Incident Management: Issues and Tactics, Springfield, 2003, pgs 40-43
}

fundamentalist groups used terrorism as a means of making their demands met. Terrorism has now developed in its evils and manifestations to involve a lot of acts ${ }^{26}$. As states advance in the use of technology and law makers develop new strategies to tackle this evil, so also terrorist movements develop new techniques to beat such legal or security system. ${ }^{27}$

The word 'terrorism' is coined from the Latin 'terrere' which means to frighten or scare away. Looking at terrorism from the perspective given by its Latin meaning opens the discussion on the definition of terrorism up. In simple terms, people get scared away or frightened daily but terrorism is not committed on a daily basis. The terrorist makes use of acts of terror to intimidate group of people he has no political, military or physical leverage on. This is why terrorism is regarded as a tool of the few and weak. Different approaches have been used by jurists, authors and states in defining terrorism. Each of these approaches defines terrorism from a distinct angle.

In order to produce a definition of terrorism in a society where terrorism has become a great threat to every democracy scholars have conducted different researches from which they all proposed individual definitions of terrorism. Terrorists are not only private individuals fronting for ideologically motivated private terrorist organisations, but they also include a government and its officials. Terrorism does not change with its actors. According to Alex Schmid, 'terrorism is an anxietyinspiring method of repeated violent action employed by clandestine individual, group or state actors, for idiosyncratic, criminal, or political reasons, 28 .

Thornton describes terrorism as the use of violence to influence political decisions in a way that offends societal human or moral values in a symbolic way ${ }^{29}$. Thackrah describes terrorism as 'an organised system of extreme and violent intimidation to create instability within democracies. International terrorists seek to launch indiscriminate and unpredictable attacks on groups... or nations to change the politicoeconomic balance of the world ${ }^{30}$

For him, there is no agreement as to a single definition of terrorism and any argument on this may prove futile. But there is a universal agreement on its elements and motivations. Terrorism is a 'deliberate means to an end' 31 . A terrorist is inspired by a course either political or ideological. This is what distinguishes terrorism from other ordinary crimes. The terrorist is not just a blood hungry

\footnotetext{
${ }^{26}$ Such as suicide bombing, kidnapping, nuclear weapon, hijacking of aircraft, etc.

${ }^{27}$ S. Brenner, At Light Speed: Attribution and Response to Cybercrime/Terrorism/Warfare, JOURNAL OF CRIMINAL LAW AND CRIMINOLOGY, (2007) at 373

${ }^{28}$ A. Schmid, Political Terrorism, 1988, Amsterdam: North-Holland, p 28

${ }^{29} \mathrm{~T}$ Thornton, 'Terror as a Weapon of Political Agitation', in H Eckstein (ed), Internal War, London: Collier-Macmillan, 1964, p 73

${ }^{30} \mathrm{R}$ Thackrah, 'Terrorism: A Definitional Problem' in P. Wilkinson and A. Stewart (Eds), Contemporary Research on Terrorism, Aberdeen, 1987, p 24

${ }^{31}$ At page 38
} 
psychopath killing innocent civilians randomly. The terrorist kills or destroys to pass his message across the targeted audience clearly. This 'message' can only be understood when unscrupulous, un-bounden violence is employed $^{32}$. This use of violence spreads panic among a civilian population in order to intimidate a target government or authority ${ }^{33}$.

Lutz ${ }^{34}$ incorporates the definitions provided by Hoffman $^{35}$, Crenshaw ${ }^{36}$, and Claridge ${ }^{37}$ below: Terrorism involves political aims and motives. It is violent or threatens violence. It is designed to generate fear in a target audience that extends beyond the immediate victims of the violence. The violence is conducted by an identifiable organisation. The violence involves a non-state actor or actors as either the perpetrator, the victim of the violence, or both. Finally, the acts of violence are designed to create power in situations in which power previously had been lacking..., 38

These elements identified by Lutz in the above definition summarize attempts made by authors in defining terrorism. Even though it involves political aims however, not all terrorist actions are political ${ }^{39}$. This definition ignores the development in religious terrorism as extremist movements attack in furtherance of a religious course. In Nigeria, for example, a religious terrorist group called Boko Haram, guided by religious dictates, attack churches/ Christians in order to intimidate the government of the country ${ }^{40}$. Also, Al-Qaeda is not only politically motivated, but also religiously motivated. In fact, most suicide bombers are religiously motivated. This first component as identified by Lutz is true but not absolute. ${ }^{41}$

Secondly, terrorism is always violent. A threat of violence is also regarded as terrorism in most states, but this is rather going too far. An attempted murder is not of the same gravity as murder it. A threat of terror is not of the same gravity as terror. A genuine reason for the inclusion of threat of violence in the definition of terrorism is that terrorism involves the use of fear to intimidate irrespective of the way it is done. If a threat of violence spreads panic among a civilian population it ultimately qualifies as an act

\footnotetext{
${ }^{32}$ T. Opperman, 'Der Beitrag des Internationalen Rechts zur Bekampfung des Internationalen Terrorismus', in Festschrift fur Hans- Jurgen Schlochauer, 1981, pp495, 503

${ }^{33}$ P. Chalk, West European Terrorism and Counter-Terrorism: The Evolving Dynamics, Basingstoke: Macmillan, 1996, p 13

${ }^{34}$ J. Lutz and B Lutz, Global Terrorism, Routledge, $2^{\text {nd }}$ Ed, 2008, $p 9$

${ }^{35}$ B. Hoffman, Inside Terrorism, New York- Columbia U.P., 2006

${ }^{36}$ M. Crenshaw, 'Introduction: Reflections on the Effects of Terrorism', in M Crenshaw(Ed), Terrorism, Legitimacy, and Power: The Consequences of Political Violence, Wesleyan U.P., 1983, pgs 1-37

${ }^{37}$ D. Claridge, 'State Terrorism? Applying a Definitional Model', Terrorism and Political Violence, Vol 8 Issue 3, 1996, pgs 47-63

${ }^{38}$ At page 9

${ }^{39}$ R. Pape, Dying to Win: The Strategic Logic of Suicide Terrorism, New YorkRandon House, 2005, p 73

${ }^{40}$ A. Cronin, 'Behind the Curve: Globalization and International Terrorism', (2002/2003), International Security, Vol 27 Issue 3, pgs 30-58

${ }^{41}$ M. Byers, 'Terrorism, the Use of Force and International Law After September', THE INTERNATIONAL AND COMPARATIVE LAW QUARTERLY, 2002, pgs 401- 414.
}

of terrorism where it is done with a political or ideological motive. As aforementioned, terrorism has either state or non-state parties as its actors. It is perpetuated not only by private groups. State terrorism is not a thing of the past. States still directly or indirectly sponsor terrorism or terrorist organisations. It would be a misconception to restrict the definition of terrorism to non-state actors. ${ }^{42}$ Lutz noted that the violence or threat of violence involves state or non state actors as the perpetrator, victim or both. However, the state is ultimately affected by any terrorist attack. After the USA was hit by the attacks of September 11 it never remained the same both economically and politically. It affected the transport system and also day to day activities in the country. Terrorism has both psychological and physical viral effect on not only its target, but also everything surrounding it.

Schmid also gave a consensus definition of terrorism. According to him, "Terrorism is an anxiety-inspiring method of repeated violent action, employed by (semi-) clandestine individual, group or state actors, for idiosyncratic, criminal or political reasons, whereby - in contrast to assassination - the direct targets of violence are not the main targets. The immediate human victims of violence are generally chosen randomly (targets of opportunity) or selectively (representative or symbolic targets) from a target population, and serve as message generators. Threat- and violence-based communication processes between terrorist (organization), (imperilled) victims, and main targets are used to manipulate the main target (audience(s)), turning it into a target of terror, a target of demands, or a target of attention, depending on whether intimidation, coercion, or propaganda is primarily sought.",43

The challenge that these academic definitions pose however is that states differ in their perception of what terrorism is as 'a criminal act of terrorism to some will embody a legitimate act of self-determination to others ${ }^{, 44}$. Below are some definitions of terrorism as given by states.

\subsection{The United Kingdom}

Section 1 of Terrorism Act 2000 defines terrorism as follows: "terrorism" means the use or threat of action where-

(a) the action falls within subsection (2),

(b) the use or threat is designed to influence the government or to intimidate the public or a section of the public, and

(c) the use or threat is made for the purpose of advancing a political, religious or ideological cause.

(2) Action falls within this subsection if it-

(a) involves serious violence against a person,

(b) involves serious damage to property,

\footnotetext{
${ }^{42}$ Cohen, H.G. Can International Law Work? A Constructivist Expansion, BERKELEY JOURNAL OF INTERNATIONAL LAW 636 (2009).

${ }^{43}$ Ibid

${ }^{44}$ C. Joyner, 'In Search of an Anti-Terrorism Policy: lessons of the Reagan Era', Terrorism: An International Journal, Vol 11, No 1, 1988, p 30
} 
(c) endangers a person's life, other than that of the person committing the action,

(d) creates a serious risk to the health or safety of the public or a section of the public, or

(e) is designed seriously to interfere with or seriously to disrupt an electronic system.

(3) The use or threat of action falling within subsection (2) which involves the use of firearms or explosives is terrorism whether or not subsection $(1)(b)$ is satisfied.

\subsection{The United States of America}

Sections 1 and 5 of the US Federal Criminal Code define international and domestic terrorism as follows:

(1) the term "international terrorism" means activities that involve violent acts or acts dangerous to human life that are a violation of the criminal laws of the United States or of any State, or that would be a criminal violation if committed within the jurisdiction of the United States or of any State;... intended to intimidate or coerce a civilian population; influence the policy of a government by intimidation or coercion; or to affect the conduct of a government by mass destruction, assassination, or kidnapping; and occurs primarily outside the territorial jurisdiction of the United States, or transcend national boundaries in terms of the means by which they are accomplished, the persons they appear intended to intimidate or coerce, or the locale in which their perpetrators operate or seek asylum...

(2) (5) the term "domestic terrorism" means activities that involve acts dangerous to human life that are a violation of the criminal laws of the United States or of any State; appear to be intended to intimidate or coerce a civilian population; influence the policy of a government by intimidation or coercion; or affect the conduct of a government by mass destruction, assassination, or kidnapping; and occur primarily within the territorial jurisdiction of the United States.'

Also according to the US Department of Defence, terrorism involves any calculated use or threat of violence to intimidate the government for political, religious or ideological purposes ${ }^{45}$. This is similar to the definition provided by the FBI as terrorism was defined as 'the unlawful use of force or violence against persons or property to intimidate or coerce a government, the civilian population, or any segment thereof, in the furtherance of political or social objectives ${ }^{, 46}$.

\subsection{France}

\footnotetext{
${ }^{45}$ Joint Pub 1-02, Department of Defense Dictionary of Military and Associated Terms, 12 April 2001, As amended on 13 June 2007; See also US Army Field Manual No FM3-0, Ch 9 pg 37

${ }^{46}$ United States Department of Justice, FBI, Terrorism in The United States, 1998 (Terrorist Research and Analytical Center, Counter-Terrorism Section, Criminal Investigation Division, 31 December, 1998) at pg 34
}

The French Criminal Code defines act as terrorist "when they are intentionally committed by an individual entity or by a collective entity in order to seriously disturb law and order by intimidation or by terror ${ }^{47}$.

\subsection{Pakistan}

The Pakistan Anti-Terrorism Act defines terrorism as the use or threat of action designed to coerce and intimidate the government or the public or to create a sense of fear or insecurity in the society in order to advance a religious, sectarian or ethnic course $51^{48}$. It goes further to highlight different acts that comes within its definition of terrorism just like other domestic legislations

\subsection{New Zealand}

The New Zealand Terrorist Suppression Act ${ }^{49}$ defines a terrorist act as an act that constitutes an offence in a specified terrorism convention 'intended to cause in any 1 or more countries' any action ranging from intentionally causing the death one or more persons, causing serious risk to the health or safety of the population, introduction of a disease-bearing organism likely to devastate the national economy of the country, in order to induce terror in a civilian population; or to unduly compel or to force a government or an international organization to do or abstain from doing an act'.

\subsection{Nigeria}

In Nigeria, a terrorist is 'anyone who [is] involved or who causes an attack upon a person's life which may cause serious bodily harm or death; kidnapping of a person; destruction to a government or public facility, transport system, an infrastructural facility including an information system, a fixed platform located on the intercontinental shelf, public place or private property likely to endanger human life or result in major economic loss, 50

There are currently 12 international, and nine regional conventions or protocols regarding terrorism. In addition the International Convention for the Suppression of Acts of Nuclear Terrorism was open for signature and is now awaiting the required number of ratifications to enter into force' and a comprehensive convention on terrorism is currently being negotiated. Internationally, there is no consensus on a definition of terrorism. ${ }^{51}$ Nevertheless international lawyers have made many attempts over the years to define it for the purposes of drafting international laws to suppress it. Those attempts are briefly outlined below.

The first international attempt to address the legal definition of 'terrorism' occurred in the late 1920s and early

\footnotetext{
${ }^{47}$ Article 421-1 of the French Criminal Code

${ }^{48}$ Section 6 of the Pakistani Anti-Terrorism Act, 1997

${ }^{49}$ Section 4 and 5 of the Terrorism Suppression Act, 2002, No. 34

${ }^{50}$ See The Nation Newspaper, February 23, 2011

${ }^{51} \mathrm{~K}$. Abbott, Economic Sanctions and International Terrorism, VANDERBILT JOURNAL OF TRANSNATIONAL LAW, 2007, p 289
} 
1930s. In response to an increase in terrorist activity following 'World War I' a series of meetings was held under the auspices of the international Conference for the Unification of Penal Law, in various European capitals. The meetings were attended by delegations representing states, intergovernmental and private international organizations. The term 'terrorism' was expressly used for the first time in an international penal instrument at the Third (Brussels) International Conference for the Unification of Penal Law in 1930 .

Attempts to suppress terrorism continued throughout the 1970 s in a piecemeal fashion. The UN issued its Declaration n Principles of International Law Concerning Friendly Relations and Cooperation between States in 1970 which provided. inter alia, that each state had the duty to refrain from encouraging the organization of armed bands irregular forces and mercenaries for incursion into the territory of another state and that each state had a "duty to refrain from organizing, instigating, assisting or participating in acts of civil strife or terrorist acts in another State or acquiescing in organized activities within its territory directed towards the commission of such acts."

One further document of note was the council of Europe's Convention on the suppression of Terrorism. Its adoption was prompted by a desire to take effective measures against the increase in acts of terrorism and to prosecute and punish perpetrators of such acts. This Convention was mainly concerned with facilitating the extradition of persons who had committed terrorist like crimes. It did not define terrorism but it was implied that all five of the categories of act referred to in Articles 1 and 2 were acts of terrorism. This one commentator has observed that the European Convention represents a legal definition of terrorism as an enumerated series of specific criminal acts even through there was no linkage of the acts via common characteristics or elements such as intent or motive, identity of the act or identity of the victim.

The question of whether and how to define the crime of terrorism is one that raises a series of intriguing and difficult questions: intriguing, because the international community has been devoting unprecedented attention to the categorical condemnation of this (undefined) crime; and difficult, because efforts to define terrorism seem destined perpetually to evoke the most volatile, partial, and situation-driven of State sensitivities. ${ }^{53}$ The following brief discussion argues that recent endeavours at the international level to establish a comprehensive definition of terrorism raise serious concerns from a human rights perspective. It argues, moreover, that greater efforts must be made to ensure that any results emerging from these negotiations take into consideration their impact on existing principles

\footnotetext{
${ }^{52}$ R. Giles-Carnero, Terrorist Acts as Threats to International Peace and Security, in P. Fernández-Sánchez (ed.), INTERNATIONAL LEGAL DIMENSION OF TERRORISM, 2009, pgs 55-71

${ }^{53}$ M. Glennon, The Fog of Law: Self-Defense, Inherence, and Incoherence in Article 51 of the United Nations Charter, HARVARD JOURNAL OF LAW AND PUBLIC POLICY, 2002, pg 539.
}

of international humanitarian law (hereinafter "IHL") as well as on the progressive advancement of international human rights standards and principles. Without such an approach, an internationally sanctioned definition of terrorism may run contrary to tendencies that have recently defined the development of international law, increasing rather than reducing incoherence in the international system. Such a definition would raise more problems than it resolves.

While there is good reason to undertake a human-rights based analysis of existing or proposed definitions of the crime of "terrorism" under the national law of various jurisdictions, this paper examine efforts at the international level. At the time of writing, the United Nations remains in the midst of an uncertain process to negotiate what is referred to as a Comprehensive Convention on International Terrorism.' In the context of these negotiations, 'comprehensive' implies both the fact that the proposed convention would supply a definition that encompasses effectively all acts that might be characterized as terrorism, adopting a unified approach in place of the fragmentary or sectoral one that has characterized previous international action, and the fact that the proposed convention would provide a broad and inclusive framework for the regulation of terrorism, including mechanisms for prevention, for policy-coordination, and for repression through criminal, financial, immigration, and other administrative means.

Both the scope of the definition itself and the various means provided for its suppression through a Comprehensive Convention call for analysis from the perspective of ensuring consistency with and wherever possible enhancing the protection of international human rights standards. A wide range of internationally-recognized human rights have come under increasing pressure in the face of national and international "counterterrorism" measures, with a consequent increase in efforts to ensure that States do not take their counter-terrorist campaigns as an opportunity to weaken or ignore these rights. ${ }^{54}$ This tendency to weaken human rights protection in the name of combating terrorism is so pronounced that the author of the present piece has grave doubts that present circumstances would permit the international community to adopt a balanced convention that strengthened rather than undermined basic rights, but the present piece proceeds on the assumption that adoption of a Comprehensive Convention may well be inevitable. At a minimum, efforts to ensure rights protection in the context of counter-terrorist measures should rigorously be taken into consideration during the negotiation of Comprehensive Convention both with respect to its definition and with respect to its jurisdictional $_{55}$ cooperation, and other procedural mechanisms. 55

\footnotetext{
${ }^{54}$ A. Hamid, "Maritime Terrorism, the Straits of Malacca, and the Issue of State Responsibility", TULANE JOURNAL OF INTERNATIONAL AND COMPARATIVE LAW, 2006, pg 155.

${ }^{55}$ M. Koskenniemi and P. Leino, Fragmentation of International Law?
} 


\section{Component Elements of Terrorism}

From the definitions given examined above, certain elements can be highlighted from them as the main components of every terrorist act. In other words, an act can only be 'terrorist' when those elements are present. These constituent elements of terrorism are there to ensure that terrorism is distinguished from every other ordinary crime, thereby excluding other activities that normally should not fall under the terrorism context. These elements are drawn from the various definitions that have been advanced by scholars and states. These elements include:

1. The violent act;

2. The terrorist victim;

3. The Motive element;

These are the basic component elements of any definition of terrorism. These elements shall be briefly examined below:

The Violent Act: This element has in fact been the major consideration in the sectoral conventions on terrorism. Some versions of Terrorist conventions or legislations define terrorism from the acts that constitute it. These acts are obviously criminal offences that have been provided for under the normal domestic conventions. However there are some special acts such as suicide bombing, use of nuclear weapons such as weapon of mass destruction, damaging the natural resource or cultural heritage of the state or even 'firing on religious congregations, mosques, ... and other places of worship'. These acts that constitute terrorism differ in each domestic provision. However as earlier mentioned, certain acts have been specially recognised as terrorist under international conventions. This is the sectoral approach to defining terrorism. These acts are 'acts which, whether or not they are offences, may or do jeopardize the safety of the aircraft or of persons or property therein or which jeopardize good order and discipline on board'(1963 Tokyo convention), the unlawful seizure of aircraft (1970 Hague convention)and, acts against safety of civil aviation (Montreal Convention 1971).Others are acts against the safety of fixed platforms located on the continental shelf (1988 Protocol, 2005 Protocol), unlawful acts of violence in the airports (1988 Montreal protocol), terrorist bombing (1997 Terrorist Bombing Convention).

The Terrorist target and Victim: the strategy employed in most terrorist attack is to target the helpless innocent civilian population. Just as we know a terrorist when we see one, we also know the innocent civilian when we see one. The Additional Protocol 1 to the Geneva Convention on the Protection of Civilian Persons in time of war defines a civilian population as comprising of all persons who are civilians. Even though the terrorist attack is often targeted at the civilian population, the relative effect of the attack is felt not only by the civilian population, but also by the

Postmodern Anxieties, LEIDEN JOURNAL OF INTERNATIONAL LAW 553579 (2002). whole community in general. Every terrorist attack has physical, psychological and economical damaging effects on the state. Also, terrorists target military persons and facilities (i.e. non civilian groups) and ultimately the government. However, one major point to note here is that when it comes to terrorism, the target is not the main issue for contemplation in any definition of the term, but the ultimate goal of such terrorist attack. It does not really matter if there is in fact no casualty, what matters is the terrorist motive and goal.

The MOTIVE Element: As aforementioned, terrorism is different from other forms of crimes basically because of the moral wrongfulness attached with it in every community. This moral wrongfulness is not only in the terror that it exhibits, but also in its political, religious or ideological motivation. This is a requirement of intent and motivation. This motive element may not apply when the act is in fact sponsored by the state, although it could also be for political reasons. However, most of the definitions advanced for international terrorism is basically targeted at the private non-governmental parties which is a major misconception when it comes to who can commit an act of terror. The motive element can either be one-tiered i.e. possessing only one motive requirement ${ }^{56}$

One final point that must be mentioned under the major elements of international terrorism is the 'international character' of the attack. The attack must have a cross border element. It must also offend the United Nations provisions on international peace and security. It must 'transcend national boundary'. This is what differentiates domestic terrorism from international terrorism, although even domestic terrorism is now gradually becoming a subject of international concern.

\section{A Crime of Terrorism and Other International Crimes}

The claim that the world needs a comprehensive treatybased definition of terrorism is based in part on the assumption that international law somehow fails to prohibit or otherwise to provide sufficient obligations with respect to the conduct such a treaty would address. Without exploring every nuance of the question, it might be useful to put the debate into perspective by sketching in broad strokes the definitional terrain wherein such a definition would find its place. ${ }^{57}$

International humanitarian law and the laws and customs applicable in armed conflict, and in particular the law of war crimes, imposes individual criminal responsibility in apparently complete overlap with any conceivable definition of acts of terrorism when committed in situations

\footnotetext{
${ }^{56}$ Or two-tiered i.e. having two different forms of motive requirements e.g. Terrorism Act 2000

${ }^{57}$ A. Nissel, Tal Becker, Terrorism and the State: Rethinking the Rules of State Responsibility (Oxford: Hart Publishing, 2006), JOURNAL OF INTERNATIONAL CRIMINAL JUSTICE 245 (2007).
} 
of armed conflict (as defined by this law as the primary condition of its application). Thus, the law of war crimes with respect to acts of "terrorism" taking place in situations of armed conflict is pertinent not just where humanitarian law instruments explicitly mention terrorism," but also with respect to the many prohibited acts that, if committed with the appropriate intent and purpose, might be characterized as terrorist (hostage-taking, the using of human shields, indiscriminate targeting of civilians, etc.).' Whether on the basis of customary or conventional law, or with respect to international or internal armed conflicts, this law creates a solid basis for the imposition of individual criminal responsibility for acts of terrorism committed in the course of armed conflict.

\section{Role of the United Nations in Counter-Terrorism}

The role of the United Nations in the international community can be likened to that of the control a state government has over its people. The United Nations is the main organ responsible for international peace and security as reflected in its Charter. This organization enforces international security. How and when this is done depends on each of its bodies, both statutory and specialized.

However terrorism is a distinct crime that has a transborder effect and has been classified as a threat to international peace and security by the Security Council. As Chapter VII of the Charter provides, the Security Council is the main UN organ charged with the responsibility of fighting any threat to international peace and security. Therefore, much of the discussion shall be on the role of the Council in countering terrorism.

\subsection{The Security Council}

The Security Council is the central organ of the United Nations. Every decision that has to do with international peace or any event that threatens international security goes through the Council. This is the primary and major duty of the Council. This, however, is not the subject for discussion in this work. One issue must be determined before going further. According to its power under Article 39 of the Charter, the Council in its Resolution 1373 categorised International terrorism as a threat to international security. The question to be asked here is 'is terrorism really a threat to international security?'

In determining a threat to peace and security, the Security Council consider country-specific situations 'such as inter- or inter-state conflicts or internal conflicts with a regional or sub-regional dimension... potential or generic threats to international peace and security such as terrorist acts, the proliferation of weapons of mass destruction or the proliferation and illicit trafficking of small arms and light weapons ${ }^{58}$. This is totally at the discretion of the Security

\footnotetext{
${ }^{58}$ Actions with Respect to Threats to the Peace, Breaches of Peace, and Acts of Aggression (Chapter VII), Repertoire of the Practice of the Security council,
}

Council, although this is most times political. As the ICTY said in Tadic case, "while the 'act of aggression' is more amenable to a legal determination, the 'threat to peace' is more of a political concept. But the determination that there exists such a threat is not a totally unfettered discretion as it has to remain, at the very least, within the limits of the Purposes and Principles of the Charter" ${ }^{\prime 59}$. Even though this decision is within the purview of the Council's powers, Gill argued against the fact that terrorism should be classed as a threat to peace as is the crime of aggression and that too much power is left to the Council's discretion ${ }^{60}$.

International Terrorism, when considered in the context of state sponsorship or omission creates a 'worldwide scare'. Looking at the path of the Council in cases given the 'terrorism' tag over the years, it can be seen that state conduct, either due to participation or omission, have always been seen as a threat to international peace and security. As the preamble to the Charter provides, the responsibility of keeping the purpose of the charter alive and functional is collective. The international community is threatened when a state becomes a safe environment for terrorists to operate and also when the State itself actively participates in planning, financing or/and committing the act of terror. Examples abound as to how the Council have done this over the years ${ }^{61}$. One interesting feature of terrorism is that terrorist acts are usually carried out by non governmental organizations, and even where it is sponsored by the government, such state always plays the smart game of partially dissociating itself from the act. What does or does not constitute threat to international peace, as Kelsen observed $^{62}$, is at the sole discretion and politics of the Security Council and an argument as to the legality or illegality of such 'discretionary power' would be a mere academic waste of time.

As aforementioned, the Security Council's involvement in matters of terrorism predates $9 / 11$ by at least a decade. However, pre-9/11 initiatives were noticeably less broad and ambitious, and still largely indebted to a classical view of international peace and security. For example, measures adopted by the Council typically targeted specific states accused of having strong links to international terrorism and that were thus seen as a threat to international peace and security. This changed after $9 / 11$ when the Council adopted an anti-terror policy that was much broader in that it required all states to adopt a whole series of antiterrorism

\footnotetext{
Available at www.un.org/en/sc/repertoire/actions.shtml

${ }^{59}$ Prosecutor v. Tadic, Case IT-94-1-AR72, Appeal Chamber, Decision on Jurisdiction, 2 October 1995, paragraph 29

${ }^{60} \mathrm{~T}$ Gill, 'Legal and Some Political Limitations on the Power of the UN Security Council to Exercise its Enforcement Powers under Chapter VII of the Charter', Netherlands Y.I.L., vol. 26, 1995, p 40-42; See also Documents of the UN Conference on International Organization, New York, Vol. XII, 1945, p. 505.

${ }^{61}$ Paragraph 7 of the preamble to UNSC Resolution 731 of 1992 on the failure of the Libyan government to extradite the terrorists responsible for the Lockerbie Bombing of 21 December 1988; Paragraph 13 of UNSC Resolution 1214 of 8 December 1998 that the actions of the Afghan government in making its territory a safe haven to Osama Bin Laden and his terrorist organization (Al Qaeda) was a breach of international peace and security.

${ }^{62}$ H Kelsen, The Law of the United Nations, London, 1950, p 284
} 
measures with clear domestic incidences. The two main planks of that policy were Resolution 1373and its broad injunction to criminalize certain behaviour, and the development of an earlier Security Council sanctions regime against individuals and organizations suspected of supporting or being involved in terrorism.

Resolution 1373 is the centrepiece of the UN's post-9/11 anti-terror drive. For the first time in the United Nations' history, it obliged states to become party to certain international treaties criminalizing various forms of terrorist activity, the resolution demands of states that they adopt a series of measures against terrorism and the financing of terrorism, including freezing of assets, criminalization, and mutual assistance. The CounterTerrorism Committee, which was to become crucial to the UN's anti-terrorism strategy, was set up under Resolution 1373.The Resolution did not, however, state how the Committee should operate (this is no longer a challenge due to the influence of the CTC's first Chairman, Sir Jeremy Greenstock and the Council as a whole). The committee consists of 15 member states of the Security Council. States are required to report regularly to the Committee on the measures they have adopted. As a result, the Council has presided over what is surely one of the fastest global legislative changes in history, one with often far-reaching consequences in the domestic law and organization of UN member states ${ }^{63}$. Resolution 1373 has been criticized as an unprecedented foray of the Council into matters that should have remained within the domain of state sovereignty (and in particular the ability to voluntarily enter certain treaties or not). ${ }^{64}$ Initially, the critique was dominated by international lawyers who saw the issue mostly from a UN-constitutional perspective as an abuse of Council powers, usurping states' treaty-adopting procedures, Increasingly, however, the critique has taken a more domestic constitutional tenor, as some lawyers deplored a new threat on parliamentary sovereignty, ' and others expressed concern about the implications for human rights of laws and regulations adopted in the Security Council's name ${ }^{65}$.

One of the major challenges to the effective operation of Resolution 1373 was the fear of it being misused by states thereby infringing on the rights of the people. Even though one cannot overlook the evil lasting effects of terrorism ${ }^{66}$, it would be more evil if the right of the people being protected is sacrificed in the name of counter terrorism. Kofi Annan rightly argued that 'human rights, along with democracy and social justice, are one of the best

\footnotetext{
${ }^{63}$ In order to block every loophole in Resolution 1373 , the Security Council passed Resolution 1624 of 14 September 2005 which created the CounterTerrorism Executive Directorate (CTED).

${ }^{64}$ R McCorquodale and P Simons, Responsibility Beyond Borders: State Responsibility for Extraterritorial Violations by Corporations of International Human Rights Law, MODERN LAW REVIEW 598-625 (2007).

${ }^{65}$ Note: The Canadian Counter Terrorist regime shall be used as case study on the human rights challenges raised by Resolution 1373

${ }^{66}$ B Netanyahu, Terrorism: How the West Can Win, in B Netanyahu(ed), Terrorism: How The West can Win, Avon, 1986, 210
}

prophylactics against terrorism ${ }^{, 67}$. This is however not the case with most domestic anti terrorism legislations, especially in the post 9/11 era. The rights shortcomings of Canada's anti-terrorism policy, both those that could arguably be traced to an international injunction and those that were largely domestic, have elicited strong human rights reactions from individuals affected by them and by civil society groups. The record of international law's impact on Canada, however, is decidedly more mixed than that of Security Council initiatives when it comes to human rights $^{68}$.

There is no paucity of international human rights mechanisms that have been mobilized to deal with the terrorism issue, including mechanisms that relate to Canada Various UN bodies with human rights mandates have taken a look at Canada's performance. Canada's human rights record came up for review before the Human Rights Council under the new Universal Periodic Review system, and several states complained about what they saw as a disproportionate impact of anti-terrorism efforts on some ethnic and religious communities ${ }^{69}$. Among Human Rights Council Rapporteurs, the Special Rapporteur on Contemporary Forms of Racism and the Working Group on Arbitrary Detention have been the most active ${ }^{70}$. The Working Group, in particular, issued a scathing indictment of the security certificate system,

\section{The Role of other UN Organs in the Fight against International Terrorism}

The UN Secretary General did much by highlighting the major organs of the organisation that assist the Council in countering international terrorism ${ }^{71}$. Other than its various deliberations on having a comprehensive international framework on terrorism ${ }^{72}$, the General Assembly assists the Security Council in maintaining international peace and security by adjudicating for the collective support and cooperation of member states. The General Assembly recently passed a resolution on its strategy on effective global counter terrorism ${ }^{73}$. These strategies are a full reflection of Secretary General Ban ki-Moon's proposal in

\footnotetext{
${ }^{67}$ Kofi Annan, in his statement to the Security Council on 18 January 2002, Press Release SG/SM/8105, SC/7277. Full speech can be assessed at http://www.un.org/news/press/docs/2002/sgsm8105.doc.htm, (last assessed on 13 September 2012)

${ }^{68}$ Therefore, Canada shall be used as case study here.

${ }^{69}$ Human Rights Council- Universal Periodic Review, 3 February 2009 at www.ohchr.org/EN/HRBodies/UPR/Pages/Highlights3February2009am.aspx ( last accessed on 13 September 2012)

${ }^{70}$ ISHR's summaries of documents for the UN Commission on Human Rights, $62^{\text {nd }}$ Session and Human Rights Council $2^{\text {nd }}$ Session

${ }^{71}$ The United Nations Actions to Counter Terrorism, A publication of The Peace and Section of the Department of Public information, DPI/2439B/Rev. 4, March 2009.

72 adoption of the Declaration on Measures to Eliminate International Terrorism, 49th Session on 9th December 1994, A/Res/49/60; A/RES/51/210

${ }^{73}$ The United Nations Global Counter Terrorism Strategy, A/RES/60/288 of 8 September 2006
} 
his statement to the Assembly in 2006 that the fight against international terrorism is a collective responsibility. This Resolution cover issues such as preventing and combating terrorism $^{74}$, check and control factors that encourage terrorism ${ }^{75}$, provision of necessary support to states in countering terrorism ${ }^{76}$, and also tackling human rights challenges to the fight against terrorism ${ }^{77}$. This Resolution on the Strategies was later reviewed in 2008 by the Assembly with no difference from the original resolution, but reaffirming member States' commitment to the struggle against terrorism ${ }^{78}$.

The Secretariat, apart from its varying administrative and peacekeeping duties ${ }^{79}$, has been so active in the struggle against international terrorism. The secretariat established in 2005 the United Nations Counter-Terrorism Implementation Task Force (CTITF) charged with the responsibility of ensuring coherence and coordination in the UN Counter-terrorism agenda. The CTITF works alongside other working groups ${ }^{80}$ of the UN as well as the member States. The CTITF and member States of the UN have a 'regular channel for interaction via the General Assembly, 81

\section{Can State Agents Commit Terrorism}

In the negotiations that have taken place on a Comprehensive Convention on International Terrorism under the auspices of the United Nations, one major point of contention has been whether such a convention should exclude itself from regulating the actions of State agents and should instead encompass only non-State terrorists. This issue of the intended target rationed personae of the definition to be established has proven to be one of the most enduring issues of the negotiations. It is an issue with potentially serious consequences for the effectiveness and the very legitimacy of the Convention. ${ }^{82}$ While public discourse about terrorism frequently focuses on non- State actors, the possibility that State agents might directly or indirectly support or perpetrate acts of terrorism is something that a number of States feel has to be included in a Comprehensive Convention. The United States and its supporters, however, insist that State violence should not be within the scope of the Convention. In an effort to dampen

\footnotetext{
${ }^{74}$ Annex II to the Resolution

${ }^{75}$ Annex I to the Resolution

${ }^{76}$ Annex III to the Resolution

${ }^{77}$ Annex IV to the Resolution

${ }^{78} \mathrm{~A} / \mathrm{RES} / 62 / 272$

79 On the Functions of the Secretariat, see http://www.un.org/en/mainbodies/secretariat/ (last accessed on 14 September 2012)

${ }^{80}$ The CTITF has representatives from groups such as The International Criminal Police Organization (INTERPOL), United Nations Interregional Crime and Justice Research Institute (UNICRI), International Civil Aviation Organization (ICAO), International Monetary Fund (IMF), and so on.

${ }^{81}$ Ibid at FN 71

${ }^{82}$ Okowa, P.N. II. Case Concerning Armed Activities on the Territory of the Congo (Democratic Republic of the Congo v. Uganda), INTERNATIONAL AND COMPARATIVE LAW QUARTERLY 742 (2006).
}

the resulting criticisms, language providing for the Stateactor exclusion was put forward that implied (without really stating) that such exclusion was not tantamount to an endorsement of impunity for State agents.

\section{The United Nations' Response to Major International Terrorist Attacks}

\subsection{The Lockerbie Terrorist Attack}

On 21 December 1988, a Pan American aircraft headed to JF Kennedy Airport in New York from London Heathrow Airport was bombed by suspected suicide bombers resulting in the death of not only everyone on board the aircraft, but also some residents of Lockerbie in Scotland ${ }^{83}$. After a prolonged investigation ${ }^{84} *$ by the governments of the United Kingdom and the United States of America, the names of two Libyan terrorists was revealed as masterminding the terrorist activity ${ }^{85}$

After appropriate indictments have been passed on the two suspected terrorists by both the UK and USA governments, a demand was made to the Libyan government for the two individuals to be extradited to a different location ${ }^{86}$. They also demanded for the payment of appropriate compensation by the Libyan government. With the Libyan government's involvement in the attack and also a lack of extradition agreement between Libya and the two concerned governments, an extradition was always going to be impossible. With two options available in the aut dedere aut judicare doctrine ${ }^{87}$, Libya opted to investigate and subsequently prosecute the suspects in Libya. This obviously did not go down well with USA and UK as they doubted how sincere the Libyan government, suspected of sponsoring the attack, was going to prosecute the accused duo.

On 31 December 1991, United Kingdom and the United States of America ${ }^{88}$ approached the UN Security Council and also the General Assembly. As a result, Resolutions $731^{89}$ and $748^{90}$ were passed by the Security Council against the Libyan government led by Colonel Gaddafi. Resolution 731 urged Libya to respond to the requests of the three governments while the other economic sanctions were applied after two months through Resolution 748. Also, the resolution banned air travel and the sale of arms to Libya. These sanctions were increased after one year due to Libya's failure to comply with the dictates of the

\footnotetext{
${ }^{83} 270$ people, most of whom were Americans, died that day

${ }^{84}$ January 1989 to November 1991

${ }^{85}$ Abdelbaset Ali Mohmed Al Megrahi and Al Amin Khalifa Fhimah.

${ }^{86}$ Statement Issued by the government of the United States on 27 November

1991 on the Bombing of Pan Am 103, UN Doc. S/23308 (1991)

${ }^{87} \mathrm{C}$. Enache-Brown and A Fried, 'Universal Crime, Jurisdiction and Duty: The Obligation of Aut Dedere Aut Judicare in International Law' (1998) 43 McGill LJ, 613 at 625

${ }^{88}$ Joined by France; Detailed in UN Doc. A/46/825

${ }^{89}$ UN SC Resolution 731 of 21 January 1992

${ }^{90}$ UN SC Resolution 748 of 31 March 1992
} 


\section{Council $^{91}$.}

Libya responded to these sanctions by filing an action before the International Court of Justice, another organ of the United Nations, in order to restrain the UK and USA from forcing it to act against its will. The ICJ again ruled in favour of the responding governments ${ }^{92}$. Five years went by with Libya not heeding to the order of the Security Council. After an agreement between the concerned governments, it was agreed that the accused terrorists be tried in a neutral ground under the Scottish Law ${ }^{93}$. After the suspects were handed over on 5 April 1999 the Security Council suspended all sanctions against Libya.

The United Nations played its role strategically and carefully in this Lockerbie case. It involved racially, religiously and politically sections. One, a core Arab nation which provides safe haven for terrorists, and the other states, pure western civilized nations that actively fight international terrorism and aggression. This situation was obviously a threat to international peace. Therefore, the UN Security Council was right to have stepped in when it did. It could have led to war if the Security Council had not controlled the situation with the UK and USA ready to coerce Libya by any means possible. The General Assembly and ICJ were also very instrumental in bringing the terrorists to justice. The United Nations is very effective in the struggle against international terrorism where is cooperation of states, which is often lacking ${ }^{94}$

\subsection{The September 11 Terrorist Attack}

On 11 September 2001, Americans witnessed a day never to be forgotten. Nineteen Al Qaeda terrorists (suicide bombers) hijacked three passenger planes and directed them to the twin towers of the World Trade Centre in New York and the Pentagon in Washington DC respectively killing over three thousand people in the process. This however was not the first attack directed against the USA by the Al Qaeda terrorist group led by Osama bin Laden ${ }^{95}$. The emotional pain of this 911 attack was reflected upon by Mary Weems as follows:

"... they are not together and do not feel the weather.

They can hear the crews saying prayers,

Saying prayers, saying prayers.

A little girl inches.

Attached to her mother's death

\footnotetext{
${ }^{91}$ UN SC Resolution 883 of 11 November 1993

${ }^{92}$ Questions of Interpretation and Application of the 1971 Montreal Convention Arising from the Aerial Incident at Lockerbie (Libyan Arab Jamahiriya v United States of America), Provisional Measures, 14 April 1992, ICJ Reports (1992) at p 114; Questions of Interpretation and Application of the 1971 Montreal Convention Arising from the Aerial Incident at Lockerbie (Libyan Arab Jamahiriya v United Kingdom) Provisional Measures, 14 April 1992, ICJ Reports (1992) at p 3

${ }^{93}$ UN SC Resolution 1192 of 27 August 1998

${ }^{94}$ See the UN SC Resolutions 1214 of 9 December 1998 and 1267 of 15 October 1999 against Taliban

${ }^{95}$ USA embassies in Tanzania and Kenya were bombed by the Osama bin Laden led Al Qaeda group)
}

She sucks breath. She folds her hand

Over her mother's hand and gives her a kiss.

Rescue is the food she waits for, a trickle of water hits her mouth, she drinks.

A father wears a battered Brooks' Brothers suit.

His head full of Rocks, his body under blocks..." 96

The United Nations Security Council condemned this act of international terrorism ${ }^{97}$ and also called on states to take necessary measures in fighting terrorism. The event of September 2001 was revolutionary in that it paved way for the available instruments against terrorism to be implemented by states ${ }^{98}$. The United Nations needed not only to enhance state capacity to counter international terrorism, but also monitor it $^{99}$. Obviously, the September 11 terrorist attack was a blessing in disguise as it allowed for wider, stricter and much more effective cooperation in counter terrorism $^{100}$.

\section{Peaceful Resolution or Use of Force}

By article 2(4) of the UN Charter all member states are to 'refrain from the threat or use of force against the territorial integrity or political independence of any state'. This provision is wide in that it covers both the threat of force and the use of force. As Arechaga rightly said, article $2(4)$ is the 'cornerstone' of international peace and security as it ensures 'peaceful relations among states' ${ }^{101}$. Defining a threat or use of force is never an easy task. The threat or use of force in international law can either be in determined circumstances (jus ad bellum) or in times of armed conflicts (jus in bello). The closest attempt at defining the use of force was the attempt made by the United Nations General Assembly in Resolution $2625^{102}$. But one major dispute that still exists among political leaders is whether the threat or use of force is restricted to military force or it actually extends to both political and economic coercions as the charter does not state in clear terms its scope. Bowett noted that it is a matter of common sense to interpret the threat or use of force to refer to only physical and armed conflict $^{103}$.

International terrorism is a threat to international peace,

\footnotetext{
${ }^{96}$ W Weems, "Blood", "Under the World, 9/22/01", in N Denzin and Y Lincoln, 9/11 In American Culture, AltaMira (2003) at 2-3

${ }^{97}$ UN SC Resolution 1373

${ }^{98}$ As was noted by the former UN Secretary General Kofi Annan, 'the fight against international terrorism must begin with ensuring that the ... legal instruments on terrorism ... are signed, ratified and implemented without delay by States'

${ }^{99}$ P Szasz, The Security Council Starts Legislating, (2002) 96 AJIL, at 902

${ }^{100}$ This 911 event had effect on subsequent terrorist attacks in UK(UN SC Resolution 1611 of 7 July 2005) and Spain( UN SC Resolution 1530 of 11 March 2004

${ }^{101}$ Jimenez de Arechaga, International Law in the Past Third of a Century, 159 Hague Recveil 9, 87 (1978)

102 Declaration on Principles of International Law Concerning Friendly Relations and Cooperation Among States In Accordance with the Charter of the United Nations, 24 October 1970

${ }^{103}$ D. Bowett, Self Defence in International Law, (1958)
} 
and if left unchecked could deteriorate to the international crimes of genocide, aggression and even crime against humanity. These international crimes all attract the Chapter VII enforcement powers of the Security Council. However, when it comes to international terrorism, necessary precautions is taken by the United Nations as terrorism is motivated by either religion, politics or even ideological beliefs of the perpetrators, unlike the other international crimes. It is a different case where the act of terror is sponsored by a State. Although the Security Council was relatively quiet about it, it supported the actions of the United States of America against Taliban and Iraq in response to the September 11 terrorist attack. Also, the Security Council was always ready to apply military sanctions against Libya in the Lockerbie trials if the Libyan government refused to surrender the suspected terrorists.

Nonetheless, when it comes to terrorist groups that are not sponsored by any state government, the discretion on how to fight the war against these groups is best left to the territorial state. But as shall be seen in the next chapter, the best remedy against international terrorism lies in collective responsibility of states.

It is no secret that terrorism poses increasingly difficult challenges for international law, along with the enforcement and elaboration of international legal norms. In fact, several recent studies have attempted to elucidate the relationship between international law and terrorism, while drawing on the benefits that can be derived from the former to combat the latter. Modern terrorists wield a considerably expanded scope of reach and influence. Modern technology not only provides them unparalleled access to new and devastating weaponry, but also allows them to broadcast their messages of intimidation and intolerance in unprecedented fashion on a truly global stage, and to a highly captive audience. Indeed, it is undoubtedly with horror that the world recently watched the events of the Mumbai terrorist attacks unfold on television and over the Internet in realtime. ${ }^{104}$ These types of private actors egregiously subvert the rules of international law and obfuscate the requisite nexuses between states and individuals upon which the traditional application of international legal norms is painstakingly dependent. On a primary level and remaining oftentimes indistinguishable from the civilian populations in which they seek solace, those private terrorist entities may operate in state-like fashion and inflict broad-reaching transnational violence across borders and cultures, while eluding state-like responsibility. As a corollary, the more diffused and highly de-hierarchized model of terrorism engendering massive and large-scale attacks is of relatively recent vintage.

But aside from the obvious and moving on to a more general level, terrorism poses a new and singular problem for international law. Perhaps emerging from the vestiges of the antiquated 'foreign office' model of public international

\footnotetext{
${ }^{104}$ A. Hamid, Maritime Terrorism, the Straits of Malacca, and the Issue of State Responsibility, TULANE JOURNAL OF INTERNATIONAL AND COMPARATIVE LAW 155 (2006).
}

law, and decidedly borne out from the now-prevalent phenomenon of the disaggregated state, the repression of privately inflicted transnational violence falls outside of the ambit of traditional international legal protection, at least at the state level. Historically, international law has been far more concerned with potential usurpation of sovereign powers and privileges, breaches of territorial integrity, and inter-state violence than with internationally wrongful acts carried out by non-state actors. In addition, the norms governing the use of force consistently responded to a unitary typology, while the recourses offered rested on predominantly bilateral conceptions of international legal relationships. Human rights protections similarly sought to extend to populations suffering under domination and mistreatment carried out by their own governments. In such -- albeit challenging -- scenarios, international law had a clear frame of reference in assigning blame: such exercise invariably pointed in direction of the nation-state. However, from a lex ferenda perspective the debate surrounding state responsibility increasingly takes stock of contemporary developments pertaining to the involvement of private actors and individuals on the international scene.

Granted, in some sectors private actors have sought to elude regulation by self-regulating, through the adoption of corporate codes of conduct for example, or by reference to soft law regimes. As certain facets of international law shift away from a state-centric paradigm to an increasingly transnational reality, however, non-state actors now challenge the rules of state responsibility, at least by their actions, and propel to the fore the need to revisit legal frameworks so as to bolster and identify potential deterrence models in order to prevent and suppress terrorism. ${ }^{105}$ Certainly, responding after the fact is important in terms of allocating blame, but a sharp focus should nonetheless be placed on prevention; international legal rules should be harnessed with an equal view to allocating risk and to stamping out the roots of transnational terrorism. It becomes clear from recent events that terrorism is a polymorphic threat - it's very practice in various permutations, whether translating in large-scale and massive attacks, more subtle, isolated strikes or Internetbased intimidation, for instance, seems to slip between the cracks of traditional international law enforcement.

Preventing terrorism has undoubtedly become a pressing social phenomenon: its authors often do not possess a fixed address; they often blend indiscriminately within the civilian populations that host them; they may operate rather autonomously and without much state support; and, in most cases, they certainly do not display any kind of regard for the rules of international law, the principle of reciprocity or the punishment/deterrence dichotomy. IDecidedly, international criminal law has a role to play in repressing terrorism and it partially attains this objective through the channel of ad hoc international criminal tribunals, namely

\footnotetext{
${ }^{105}$ R. Giles-Carnero, Terrorist Acts as Threats to International Peace and Security, in Pablo Antonio Fernández-Sánchez (ed.), INTERNATIONAL LEGAL DIMENSION OF TERRORISM 55-71 (2009).
} 
under the Statute of the International Criminal Tribunal for Rwanda, which incorporates the crime of 'terrorism' within the furrow of the Tribunal's expertise. ${ }^{106}$

Other international instruments and arrangements similarly focus on holding the perpetrators of terrorism accountable under international law. Yet, it is important to note that international criminal law is, by no means, the default regime for repressing and preventing terrorism. In fact, several factors such as the Annex to the Rome Statute of the International Criminal Court and the criminalization under domestic law of behaviours that, historically, solely amounted to evidentiary elements in criminal cases (e.g. registration in private flight/pilot schools, procurement of sources on explosive-making, dissemination of certain types of speech, membership in certain groups, etc.), clearly point in the direction of domestic criminal law as the preferred regime for holding individuals accountable. The international criminal model, therefore, is an interesting exception to the default regime that is undoubtedly acquiring traction, but that remains nonetheless limited and certainly constrained by jurisdictional, conceptual and political impediments. Whilst certain initiatives aiming to bolster individual accountability on the international scene are laudable, they fall short in ensuring the accountability of those states that harbour terrorists or in better circumscribing the potential role(s) that states play in supporting or in failing to prevent terrorism.

Of vital importance to this topic are the conclusions formulated by the United Nations mandated High-level Panel on Threats, Challenges and Change in its report, titled A More Secure World. Indeed, the Panel proclaimed that, "States are still the front-line responders to today's threats. Successful international actions to battle poverty, fight infectious disease, stop transnational crime, rebuild after civil war, reduce terrorism and halt the spread of dangerous materials all require capable, responsible States as partners. It follows that greater effort must be made to enhance the capacity of States to exercise their sovereignty responsibly."107

\section{Relationship between State Responsibility and Terrorism}

The relationship between state responsibility and terrorism becomes particularly relevant, and compelling, when one considers that Iran recently provided missiles and other types of weaponry to Hezbollah factions in their attacks against Israel, or that the government of Afghanistan afforded members of Al Qaeda the opportunity

\footnotetext{
${ }^{106}$ J. Ellis, Has International Law Outgrown Trail Smelter?, in R.M. Bratspies and R.A. Miller (eds.), TRANSBOUNDARY HARM IN INTERNATIONAL LAW: LESSONS FROM THE TRAIL SMELTER ARBITRATION 56-65 (2006).

${ }^{107}$ Cohen, H.G. Can International Law Work? A Constructivist Expansion, BERKELEY JOURNAL OF INTERNATIONAL LAW 636 (2009).
}

to seek refuge on its territory prior to the $9 / 11$ attacks. In such difficult factual scenarios -- where international criminal justice is often eschewed or short-circuited because of the inability to capture or produce the suspected terrorists -- the international community must seek ways to buttress the application of accountability mechanisms to complicit or involved governments, so as to fight impunity and prevent further terrorism ${ }^{108}$.

Before embarking upon a review of potential levels of governmental involvement in terrorism, a healthy dose of political realism seems apposite here. In particular, any study attempting to recast the rules of state responsibility with certain policy objectives in mind will inexorably have to grapple with the idea that the uncertainty surrounding potential legal responses to terrorism will be exacerbated by the margin of appreciation wielded by states (particularly aggrieved ones) as to what constitutes 'terrorism'. This will also have significant implications for the interrelationship between auto qualification and state responsibility, a symbiosis that will be further explored). More importantly, the compliance pull of primary counterterrorism obligations will unquestionably remain informed and shaped by the resources at the disposal of states in combating terrorism. For instance, it may well be that a state possessing scarce resources decides that it would not be justified in diverting them towards counterterrorism programmes. To counteract this eventuality, and as will be explored in subsequent pages, arguments are increasingly put forth that such states have a positive duty under international law to acquire the requisite counterterrorism capacity and, as a corollary, to harness it with a view to stamping out terrorism percolating within their borders. ${ }^{109}$

It becomes apparent that "states may not be directly implicated in acts of terrorism, but there is a spectrum of state responsibility, ranging from simply being unable to prevent terrorists from using its territory as a base for carrying out such activities, through to actually providing full assistance or control over them." It must be stressed that, at the 'direct involvement' end of the spectrum we find states that are flat-out complicit in terrorism or that wage specific military and paramilitary initiatives through a surrogate terrorist organization that they fully control. At the 'indirect involvement' end, we may be faced with simply negligent states that fail to freeze the assets of terrorist groups or merely tolerate the presence of terrorists on their territory without endorsing any of their activities, simply because they are unable to repel them.

More importantly, it is vital to underscore that both of these extreme scenarios could potentially trigger the law of

\footnotetext{
${ }^{108}$ J.I. Charney, Third State Remedies in International Law, 10 MICHIGAN JOURNAL OF INTERNATIONAL LAW 57-101 (1989), reprinted in René Provost (ed.), STATE RESPONSIBILITY IN INTERNATIONAL LAW 205250 (2002).

109 M. Drumbl, Terrorist Crime, Taliban Guilt, Western Victims, and International Law, DENVER JOURNAL OF INTERNATIONAL LAW \& POLICY 69-79 (2002).
} 
state responsibility, while the actual degree of liability might remain contingent on, or commensurate with, the level of harm inflicted through the commission of the internationally wrongful act. In fact, a common but perhaps erroneous reading of the authoritative jurisprudence in this field might infer that "applying the authority provided by the Corfu Channel Case to the current international crisis of state-sponsored terrorism, a State cannot knowingly acquiesce to terrorist activity within its borders without assuming liability." However, given a translation discrepancy associated with that decision, it is probably fair to argue that the 'consent' or 'knowledge' component should be excised altogether from the primary obligation extracted from the Corfu Channel case ${ }^{110}$. More specifically, the French of the original judgment frames the relevant obligation as a duty "pour tout Etat, de ne pas laisser utiliser son territoire aux fins d'actes contraires aux droits d'autres Etats", while the English translation rather invokes an "obligation not to allow knowingly its territory to be used for acts contrary to the rights of other States." 111 Whilst the issue of knowledge will be further engaged in subsequent sections, one can see at the outset that the English translation carries, with it, a more onerous burden for establishing responsibility, namely the requirement of knowledge by the host-state that harmful activity is being launched from its territory in order to trigger its international responsibility. In sum, because the French version of the text is authoritative, the obligation of prevention rather entails that host-states ensure that their territories are not used for activities injurious to third parties and/or states. ${ }^{112}$ Put another way, a severe obligation may be extracted from the Corfu Channel ruling to the effect that states may not allow their territories to be used as launch pads for terrorist excursions, irrespective of whether the involved governments acquiesced to the activities or, arguably, were even cognizant of such operations. $^{113}$

Similarly, the language associated with post-911 state responsibility law has been rather divisive. While some scholars minutely delve into semantics laden incursions seeking to elucidate the vernacular emerging from years of state support in the Afghanistan-Al Qaeda or IranHezbollah scenarios, for example, others completely discard such endeavours. From a 'qualitative' (to which one should add - 'quantitative' - in some cases) standpoint, it can be asserted that the notions of 'state sponsorship' and 'state support' may, in fact, signal two varying types of state participation in terrorism. In a post-9/11 account, one

\footnotetext{
${ }^{110}$ Corfu Channel Case (United Kingdom v Albania) ICJ Reports 1949, p 4

${ }^{111}$ Calamita, N.J. Sanctions, Countermeasures, and the Iranian Nuclear Issue, VANDERBILT JOURNAL OF TRANSNATIONAL LAW 1393 (2009).

${ }^{112}$ Brownlie, I. The Responsibility of States for the Acts of International Organizations, in Maurizio Ragazzi (ed.), INTERNATIONAL RESPONSIBILITY TODAY: ESSAYS IN MEMORY OF OSCAR SCHACHTER 355-362 (2005).

113 Brenner, S. At Light Speed: Attribution and Response to Cybercrime/Terrorism/Warfare, JOURNAL OF CRIMINAL LAW AND CRIMINOLOGY 379 (2007).
}

author declares that "state sponsorship of terrorism is limited to situations where the state planned, directed, and controlled terrorist operations and state support of terrorism includes all other lesser forms of state involvement." 114

Similarly, in her 2001 Progress Report on Terrorism and Human Rights, Special Rapporteur Kalliopi Koufa noted that - whilst both terms engender considerable confusion when transplanted into the sphere of state practice - they embody distinct legal meanings, with the notion of 'state support' inherently carrying a lesser form of governmental involvement and control over terrorist activity (e.g. tacit support, logistical support, providing sanctuary, etc.). Consequently, governments, media and other institutions frequently and liberally brandish these terms for a dual purpose: by pure sensationalistic or propagandistic inclination, or to actually cast judgment on, or pronounce on the legal responsibility of, specific host-states vis-à-vis a terrorist attack. ${ }^{115}$ However, this particular construction of those notions failed to acquire credence in some academic circles, with several members of the American Society of International Law's Committee on Responses to StateSponsored Terrorism voicing their "dissatisfaction with the terms 'state sponsorship' and 'state support' on the ground that these terms lack precise legal content." Nevertheless, it inevitably follows that "state sponsorship and state support of terrorism are solidly entrenched in the discourse of terrorism and are powerful expressions of state complicity, guilt, and participation in acts of terror. As such, these terms serve an important political and legal function, connecting states, which surreptitiously assist terrorists, to their terrible crimes." ${ }^{116}$ Consequently, specific levels of governmental input and participation in terrorist activities will be canvassed throughout this project. In the interim, it is imperative to briefly survey potential scenarios on the gradation of state failures in preventing terrorism, in order to shed light on the shortcomings of state responsibility. ${ }^{117}$

Given the international community's will to eradicate terrorism, coupled with the Council's emphatic condemnation of terrorist acts and its resolve to eliminate threats to peace and security "by all necessary means", it is imperative to rethink the underlying tenets of indirect responsibility. Although it is also important to address the substantiality of a state's obligation to prevent terrorist attacks, the trans-substantive rules of state responsibility must also be revisited in light of the paradigm shift described above. The thrust of the policy argument advanced in this chapter, therefore, is that the interests and priorities of the international community, especially with regard to combating terrorism, would be better achieved by

\footnotetext{
${ }^{114}$ R. B. Bilder, The Role of Apology in International Law and Diplomacy, VIRGINIA JOURNAL OF INTERNATIONAL LAW 433 (2006).

${ }^{115}$ E. Benvenisti, The US and the Use of Force: Double-Edged Hegemony and the Management of Global Emergencies, EUROPEAN JOURNAL OF INTERNATIONAL LAW 677 (2004).

116 M. Bedjaoui, Responsibility of States, Fault and Strict Liability, ENCYCLOPEDIA OF PUBLIC INTERNATIONAL LAW 358-362 (1987).

117 Bederman, D.J. Counterintuiting Countermeasures, AMERICAN JOURNAL OF INTERNATIONAL LAW 817 (2002)
} 
circumventing certain trans-substantive rules, namely attribution. This line of reasoning seems reminiscent or on par with certain precursory statements articulated in legal scholarship prior to 9/11. In a somewhat premonitory statement with regard to the current debate, Gordon Christenson raised the possibility of rethinking attribution in order to better reflect modern reality. He noted that "the tradition of civil society with intermediate institutions that are neither market nor State offers a form of pluralism to rethink the international legal order's attention to attribution theory. Allocating supervisory responsibility and control to conduct of modern States in relation to non-State actors in an exclusive system of territorial States will revise attribution theory to reflect the new realities of power."118

The defect, therefore, is one of adaptability of a statecentric legal system to transnational phenomena, such as terrorism, so as to best integrate a multiplicity of actors within a multipolar political reality. Having now identified these conceptual and legal shortcomings -- along with a potential paradigm shift in both state and institutional practice towards mustering the requisite political will to move towards more indirect modes of international responsibility -- the dissertation now turns to more tangible policy recommendations. In so doing, it remains challenged by the hard cases canvassed above, namely where the hoststate's involvement is sufficiently divorced from the private perpetration of transnational terrorism to eschew the classical rules of attribution. ${ }^{119}$ For instance, the scenario explored above whereby Lebanon fails to control the southern portion of its territory, which is, in turn, used as a launch pad for attacks carried out by Hezbollah factions remains a quintessential encapsulation of the legal 'grey area' that the present project seeks to elucidate. In response to such scenarios, some commentators have rightly called for a rethinking of the rules of attribution so as to better address the modern challenges of terrorism. Yet, too little scholarly emphasis has been placed - or, conversely, has been misplaced in some cases - on critically appraising and reconceptualising the rules of state responsibility. With this vital concern in mind, this first section will therefore canvass the key points of contention triggered by post-9/11 scholarly shortcomings warranting further consideration in order to fully set out a proposal for policy reform.

Both before and after 9/11, the inadequacy of the prevalent scheme of state responsibility in dealing with terrorism while placing significant emphasis on the shortcomings of the Nicaragua and Tadic formulations of attribution, especially in light of host-states waging surrogate warfare via subterfuges or wilful blindness was apparent. Among similar lines and after canvassing some of the conceptual problems related to the response to $9 / 11$, it

\footnotetext{
118 Bennouna, M. La Protection diplomatique: Du standard minimum de traitement des étrangers aux droits de l'Homme, MELANGES EN L'HONNEUR DE KALLIOPI KOUFA 1-6 (2010).

${ }^{119}$ Bassiouni, M.C. Legal Control of International Terrorism: A Policy-Oriented Assessment, HARVARD INTERNATIONAL LAW JOURNAL 83-103 (2002).
}

can also be argued that the current state-to-state scheme of responsibility is "inadequate to assure the observance of international law." Conversely, following 9/11 some of the criticism pertaining to the possible shift in the law of state responsibility deplored the revision of trans-substantive rules of responsibility over the primary rules of international law. For reasons explored previously, the present section of the study elects to cast part of its proposal for reform at the level of secondary norms and, as prefaced above, starts by briefly canvassing the shortcomings of existing post-9/11 literature so as to identify the specific areas in need of further academic consideration. 120

\section{Revisiting Trans-Substantive Rules}

The reasoning underpinning the present study takes issue with the claim that revising trans-substantive rules, especially attribution, would not yield effective results. The global effort against terrorism is an exercise in risk assessment. As explored above, the philosophical questions raised by the "war" on terror definitely have Kantian roots and lend themselves to several ethical, social, and philosophical considerations. Kant's theory that a human being should not be used as a means toward the collective well-being comes to mind and bolsters the proposition that we should not balance human lives in the name of collective security, for instance. ${ }^{121}$ As a corollary to this categorical imperative, it follows that the present legal reform exercise inexorably touches upon the struggle between collective rights and individual rights, and further reinforces the need to rethink the scheme of state responsibility in that light. Furthermore, it follows that "the increase in individuals' human rights is inevitably accompanied by an increase in their responsibility for human wrongs, even when committed under the colour of state authority." Starting from that premise, there are no ideal scenarios or perfect solutions. Hence, mitigation of the disparity in political and economic power between states, coupled with the essential goal of saving lives, remains a noble objective. For instance, the prevalent scheme of state responsibility, or rather the implications of its application to terrorist activity and/or war-time activities, should always bear in mind essential principles of international law, such as the protection of civilians and the sovereign equality between states.

\section{Conclusion}

This is not to say, however, that the notion of control should be excised altogether from the range of

\footnotetext{
${ }^{120}$ Bilder, R.B. The Role of Apology in International Law and Diplomacy, VIRGINIA JOURNAL OF INTERNATIONAL LAW 433 (2006).

${ }^{121}$ Brown, D. Use of force Against Terrorism After September 11th: State Responsibility, Self-Defense and Other Responses, CARDOZO JOURNAL OF INTERNATIONAL AND COMPARATIVE LAW 1-53 (2003)
} 
considerations governing the establishment of indirect responsibility for terrorism. Rather, the determinant factor should turn on the host-state's failure to control its territory and, as a corollary, any harmful terrorist activities emanating from its soil. Similarly to the reasoning underlying Corfu Channel, the question of knowledge might become pivotal in establishing the state's responsibility: "where the loss complained of results from acts of individuals not employed by the state, or from activities of licensees or trespassers on the territory of the state, the responsibility of the state will depend on a failure to control. In this type of case questions of knowledge may be relevant in establishing the omission or, more properly, responsibility for failure to act." It must pertinently be recalled that, in Corfu Channel, the Court predicated Albania's knowledge of the presence of the minefield in its territorial waters on the fact that the government closely and routinely monitored the area where the mines were laid. Again, this viewpoint must be carefully balanced out by the error in translation found in the Corfu Channel judgment described above, which may have opened the door to logic of indirect, no-knowledge state responsibility. ${ }^{122}$

The resistance to domestic law transplantations in international law has carried over to other spheres, such as the law of international organizations and international criminal law. Granted, in the latter case this resistance has considerably waned and paved the way for international criminal law to be considerably shaped and influenced by domestic criminal law. In sum, by analyzing the possible contribution of certain legal traditions to state responsibility, the present dissertation is guided by a simple precept: "the borrowing of law is the primary instrument of law's development." ${ }^{123}$ In other words - and in stark contrast with the view that an independent international legal order can only export its components vertically into the civil/common law divide - the law of state responsibility undoubtedly amounts to a mixture of different legal influences, particularly when deploying its fundamental mechanisms.

Thus, it is no surprise that "in theory and in practice, the international law of responsibility is applied across the field of international obligations. It comprises areas that -in terms of domestic analogies -- may be seen as like those of contract and tort, and others that might be seen as analogous to public law." ${ }^{124}$ It is safe to say at this point that the best remedy against international terrorism is state cooperation and state responsibility. It does not matter how many instruments that are present against international and/or domestic terrorism. What matters is the cooperation of member states of the United Nations Organisation. 1

\footnotetext{
${ }^{122}$ Brunnée J. and Toope S.J. The Use of Force: International Law After Iraq, INTERNATIONAL AND COMPARATIVE LAW QUARTERLY 785-806 (2004).

${ }^{123}$ Brown, D. Use of force Against Terrorism After September 11th: State Responsibility, Self-Defense and Other Responses, CARDOZO JOURNAL OF INTERNATIONAL AND COMPARATIVE LAW 1-53 (2003)

${ }^{124}$ Boyle, A.E. Globalising Environmental Liability: The Interplay of National and International Law, JOURNAL OF ENVIRONMENTAL LAW 3 (2005).
}

\section{References}

[1] A Cassesse, International Criminal Law, (2nd ed, OUP, 2008) 162-165;

[2] A Cassesse, 'Terrorism as an International Crime', in A Bianchi (ed), Enforcing International Law Norms Against Terrorism (Hart Publishing, 2004)

[3] A Schmid, "The Response Problem as a Definition Problem" in J Lutz and B Lutz (eds), Global

[4] A Roberts, 'Terrorism and International Order' in L Freedman et al (eds), Terrorism and International Order, (Routledge \& Keegan Paul, 1986) 7

[5] A. Nussbaum, A Concise History of the Law of Nations, (Macmillan, 1954) 1-2

[6] A. Abass, Proving State Responsibility for Genocide: The ICJ in Bosnia v. Serbia and the International Commission of Inquiry for Darfur, 31 FORDHAM INTERNATIONAL LAW JOURNAL 871 (2008).

[7] Abbott, K.W. Economic Sanctions and International Terrorism, 20 VANDERBILT JOURNAL OF TRANSNATIONAL LAW 289 (2007).

[8] Abbott, K.W. International Relations Theory, International Law, and the Regime Governing Atrocities in International Conflicts, 93 AMERICAN JOURNAL OF INTERNATIONAL LAW 361 (1999).

[9] Abbott, K.W. Modern International Relations Theory: A Prospectus for International Lawyers, 14 YALE JOURNAL OF INTERNATIONAL LAW 335 (1989).

[10] Abeyratne, R. The Responsibility of Somalia for the Acts of the Somali Pirates, 2 JOURNAL OF TRANSPORTATION SECURITY 63-76 (2009).

[11] Abramowitz, D. The President, Congress, and Use of Force: Legal and Political Considerations in Authorizing Use of Force Against International Terrorism, HARVARD INTERNATIONAL LAW JOURNAL 71-103 (2002).

[12] Addicott, J.F. Legal and Policy Implications for a New Era: The "War on Terror", THE SCHOLAR: ST. MARY'S LAW REVIEW ON MINORITY ISSUES 209 (2002).

[13] Ahdieh, R.B. Between Dialogue and Decree: International Review of National Courts, NEW YORK UNIVERSITY LAW REVIEW 2029 (2004).

[14] Aldrich, G.H. The Taliban, Al Qaeda, and the Determination of Illegal Combatants, AMERICAN JOURNAL OF INTERNATIONAL LAW 891 (2002).

[15] Alvarez, J.E. Hegemonic International Law Revisited, AMERICAN JOURNAL OF INTERNATIONAL LAW 873 (2003).

[16] Amerasinghe, C.F. The Essence of the Structure of International Responsibility, in Maurizio Ragazzi (ed.), INTERNATIONAL RESPONSIBILITY TODAY: ESSAYS IN MEMORY OF OSCAR SCHACHTER 3-6 (2005).

[17] Arai-Takahashi, Y. Shifting Boundaries of the Right of SelfDefence - Appraising the Impact of the September 11 Attacks on Jus Ad Bellum, INTERNATIONAL LAWYER 
1081-1102 (2002).

[18] Article 39 of the UN Charter

[19] Atapattu, S. Sustainable Development and Terrorism: International Linkages and a Case Study of Sri Lanka, 30 WILLIAM \& MARY ENVIRONMENTAL LAW \& POLICY REVIEW 273 (2006).

[20] Bâli, A. Stretching the Limits of International Law: The Challenge of Terrorism, ILSA JOURNAL OF INTERNATIONAL AND COMPARATIVE LAW 403-416 (2002).

[21] Banks, M.M.D. Addressing State (Ir-)Responsibility: The Use of Military Force as Self-Defense in International Counter-Terrorism Operations, 200 MILITARY LAW REVIEW 54 (2009).

[22] Bassiouni, M.C. Legal Control of International Terrorism: A Policy-Oriented Assessment, HARVARD INTERNATIONAL LAW JOURNAL 83-103 (2002).

[23] Battaglini, G. War Against Terrorism Extra Moenia, SelfDefence and Responsibility: A Pure Judicial Approach, in Maurizio Ragazzi (ed.), INTERNATIONAL RESPONSIBILITY TODAY: ESSAYS IN MEMORY OF OSCAR SCHACHTER 137-149 (2005).

[24] Bederman, D.J. Counterintuiting Countermeasures, AMERICAN JOURNAL OF INTERNATIONAL LAW 817 (2002).

[25] Bedjaoui, M. Responsibility of States, Fault and Strict Liability, ENCYCLOPEDIA OF PUBLIC INTERNATIONAL LAW 358-362 (1987).

[26] Bennouna, M. La Protection diplomatique: Du standard minimum de traitement des étrangers aux droits de l'Homme, MELANGES EN L'HONNEUR DE KALLIOPI KOUFA 1-6 (2010).

[27] Benvenisti, E. The US and the Use of Force: Double-Edged Hegemony and the Management of Global Emergencies, EUROPEAN JOURNAL OF INTERNATIONAL LAW 677 (2004).

[28] Bilder, R.B. The Role of Apology in International Law and Diplomacy, VIRGINIA JOURNAL OF INTERNATIONAL LAW 433 (2006).

[29] Bloom, C. The Classification of Hezbollah in Both International and Non-International Armed Conflicts, ANNUAL SURVEY OF INTERNATIONAL ANDCOMPARATIVE LAW 61 (2008).

[30] Boyle, A.E. Globalising Environmental Liability: The Interplay of National and International Law, JOURNAL OF ENVIRONMENTAL LAW 3 (2005).

[31] Brazilian Minister of Foreign Affairs, Celso Lafer, in his speech at the XXII Meeting of Consultation of the ministers of Foreign Affairs in the Organization of American States of Washington DC (September 21, 2001), available at http://www.patriotresource.com/wtc/intl/0921/brazil.html accessed 4 July 2012

[32] Brenner, S. At Light Speed: Attribution and Response to Cybercrime/Terrorism/Warfare, JOURNAL OF CRIMINAL LAW AND CRIMINOLOGY 379 (2007).
[33] Brown, D. Use of force Against Terrorism After September 11th: State Responsibility, Self-Defense and Other Responses, CARDOZO JOURNAL OF INTERNATIONAL AND COMPARATIVE LAW 1-53 (2003)

[34] B. Kellman, State Responsibility for Preventing Bioterrorism, THE INTERNATIONAL LAWYER 29-38 (2002).

[35] Brunnée J. and Toope S.J. The Use of Force: International Law After Iraq, INTERNATIONAL AND COMPARATIVE LAW QUARTERLY 785-806 (2004).

[36] Brunnée, J. International Legal Accountability Through the Lens of the Law of State Responsibility, NETHERLANDS YEARBOOK OF INTERNATIONAL LAW 21-56 (2005).

[37] Byers, M. Terrorism, the Use of Force and International Law After September, THE INTERNATIONAL AND COMPARATIVE LAW QUARTERLY 401 - 414 (2002).

[38] Calamita, N.J. Sanctions, Countermeasures, and the Iranian Nuclear Issue, VANDERBILT JOURNAL OF TRANSNATIONAL LAW 1393 (2009).

[39] Charney, J.I. Third State Remedies in International Law, 10 MICHIGAN JOURNAL OF INTERNATIONAL LAW 57101 (1989), reprinted in René Provost (ed.), STATE RESPONSIBILITY IN INTERNATIONAL LAW 205-250 (2002).

[40] Cohen, H.G. Can International Law Work? A Constructivist Expansion, BERKELEY JOURNAL OF INTERNATIONAL LAW 636 (2009).

[41] Dalton, J.G. The United States National Security Strategy: Yesterday, Today, and Tomorrow, NAVAL LAW REVIEW 60 (2005).

[42] De Brabandere, E. Non-State Actors, State-Centrism and Human Rights Obligations, LEIDEN JOURNAL OF INTERNATIONAL LAW 191 (2009).

[43] Drumbl, M.A. Terrorist Crime, Taliban Guilt, Western Victims, and International Law, DENVER JOURNAL OF INTERNATIONAL LAW \& POLICY 69-79 (2002).

[44] Duffy M.T. and Provost R. Constitutional Canaries and the Elusive Quest to Legitimize Security Detentions, CASE WESTERN RESERVE JOURNAL OF INTERNATIONAL LAW 531 (2009).

[45] Ellis, J. Has International Law Outgrown Trail Smelter?, in R.M. Bratspies and R.A. Miller (eds.), TRANSBOUNDARY HARM IN INTERNATIONAL LAW: LESSONS FROM THE TRAIL SMELTER ARBITRATION 56-65 (2006).

[46] Frischmann, B. A Dynamic Institutional Theory of International Law, BUFFALO LAW REVIEW 689 (2003).

[47] Gathii, J. Case Concerning Armed Activities on the Territory of the Congo (Democratic Republic of the Congo v. Uganda) (International Decision), AMERICAN JOURNAL OF INTERNATIONAL LAW (2007)

[48] Giles-Carnero, R. Terrorist Acts as Threats to International Peace and Security, in Pablo Antonio Fernández-Sánchez (ed.), INTERNATIONAL LEGAL DIMENSION OF TERRORISM 55-71 (2009). 
[49] G. Scott, The Rise and Fall of the League of Nations, (London 1973) 19-42.

[50] Gill, T.D. The Eleventh of September and the Right of SelfDefense, in Wybo P. Heere (ed.), TERRORISM AND THE MILITARY: INTERNATIONAL LEGAL IMPLICATIONS 23-42 (2003).

[51] Glennon, M.J. Does International Law Matter? AMERICAN SOCIETY OF INTERNATIONAL LAW PROCEEDINGS 315 (2004).

[52] Glennon, M.J. The Fog of Law: Self-Defense, Inherence, and Incoherence in Article 51 of the United Nations Charter, HARVARD JOURNAL OF LAW AND PUBLIC POLICY 539 (2002)

[53] Goodman R. and Jinks D. International Law, War Powers, and the Global War on Terrorism, HARVARD LAW REVIEW 2653-2662 (2005).

[54] Hamid, A.G. Maritime Terrorism, the Straits of Malacca, and the Issue of State Responsibility, TULANE JOURNAL OF INTERNATIONAL AND COMPARATIVE LAW 155 (2006).

[55] Henderson, C.M. Michael Byers, War Law: International Law and Armed Conflict, JOURNAL OF CONFLICT AND SECURITY LAW 150 (2007).

[56] Intelligence and Security Committee Report into the London Terrorist Attacks on 7 July 2005, Presented to the Parliament by the Prime Minister by command of Her Majesty, May 2006, available at http://www.officialdocuments.gov.uk/document/cm67/6785/6785.pdf accessed 4 July 2012

[57] I. Brownlie, The Responsibility of States for the Acts of International Organizations, in Maurizio Ragazzi (ed.), INTERNATIONAL RESPONSIBILITY TODAY: ESSAYS IN MEMORY OF OSCAR SCHACHTER 355-362 (2005).

[58] J Austin and J Brown (eds), The Austinian Theory of Law: Being an Edition of Lectures I, V, and VI of Austin's "Jurisprudence" and of Austin's "Essay on the Uses of the Study of Jurisprudence" with Critical Notes and Excurses, (London: J Murray, 1906) 331

[59] J Maogoto, Battling Terrorism: Legal Perspectives on the Use of Force and the War on Terror, (Ashgate Publishing Ltd, 2005)

[60] K. Abbott, R. Keohane, A. Moravcsik, A-M. Slaughter and D. Snidal, The Concept of Legalization, 54 INTERNATIONAL ORGANIZATION 401 (2000).

[61] M. Koskenniemi and P. Leino, Fragmentation of International Law?: Postmodern Anxieties, LEIDEN JOURNAL OF INTERNATIONAL LAW 553-579 (2002).

[62] M. Lippman, The New Terrorism and International Law. TULSA JOURNAL OF COMPARATIVE \& INTERNATIONAL LAW 297-368 (2003).

[63] M Dixon and R McCorquodale, Cases and Materials on International Law, (4th Ed, OUP, 2003)

[64] M. Shaw, International Law, 6th Edition, Cambridge
[65] Martinez, L. Prosecuting Terrorists at the International Criminal Court: Possibilities and Problems, RUTGERS LAW JOURNAL 1 (2002).

[66] M. O'Connell, Lawful and Unlawful Wars Against Terrorism, in Ved P. Nanda (ed.), LAW IN THE WAR ON INTERNATIONAL TERRORISM 79-96 (2005).

[67] N. Babbic and D. Zolo, 'Hans Kelsen, The Theory of Law and the International Legal System: A Talk', (1998) 9 EJIL 355-667

[68] P. Okowa, Case Concerning Armed Activities on the Territory of the Congo (Democratic Republic of the Congo v. Uganda), INTERNATIONAL AND COMPARATIVE LAW QUARTERLY 742 (2006).

[69] P Robinson, 'The Missing Crimes' in A Cassesse et al (eds), The Rome Statute of the International Criminal Court: A Commentary, (Vol I, OUP, 2002) 497-525;

[70] R Chandrasekaran, "Taliban Refuses to Surrender bin Laden: US Develops Options for Military Action", 19 Sept 2001 Washington Post at A1

[71] R. McCorquodale and P. Simons, Responsibility Beyond Borders: State Responsibility for Extraterritorial Violations by Corporations of International Human Rights Law, MODERN LAW REVIEW 598-625 (2007).

[72] R. Keohane, The Public Delegitimation of Terrorism and Coalition Politics, in Ken Booth and Tim Dunne (eds.), WORLDS IN COLLISION: TERROR AND THE FUTURE OF GLOBAL ORDER 141-151 (2002).

[73] R Jennings and A Watts, Oppenheim's International Law, (Vol I, OUP, 9th Ed, 1992) 4

[74] R. Bernhardt, Encyclopedia of Public International Law, (Vol VII, North-Holland, 1984) 150

[75] S. Rosenberg, Promoting Equality After Genocide, TULANE JOURNAL OF INTERNATIONAL AND COMPARATIVE LAW 329 (2008).

[76] S Lyman (ed), The China White Paper, (Stanford, 1967) 10; G Scott, The Rise and Fall of the League of Nation

[77] S Murphy, "Terrorism and the Concept of 'Armed Attack' in Article 51 of the UN Charter", (2002) 43 Harvard Int'l Law Journal, p 41

[78] Terrorism (Vol I, SAGE, 2008) 7; R Cryer, "Terrorism and the International Criminal Court" (2003) 82 REFORM: Journal of the Australian Law Reform Commission, pp 1416

[79] V Proulx, "Rethinking the Jurisdiction of the International Criminal Court in the Post-September 11th Era: Should Acts of Terrorism Qualify as Crimes against Humanity?" (2004) American University International Law Review, Vol 19, No 5, pp 1009-1089;

[80] V Lenin, The National Liberation Movement in the East, (Foreign Language Publishing House, Moscow, 1957) 240

[81] Y Korovin et al, International Law (Academy of Sciences of the USSR Institute of Law, Foreign Languages Publishing House, Moscow) 15-18. 